\title{
Identitas Diri pada Media Sosial (Konstruksi Sosial dan Potensi Rumor Pengguna Instagram)
}

\author{
Irwanto $^{1}$, Laurensia Retno Hariatiningsih ${ }^{2}$ \\ ${ }^{1}$ Universitas Bina Sarana Informatika \\ Email: Irwanto.iwo@bsi.ac.id \\ ${ }^{2}$ Universitas Bina Sarana Informatika \\ Email: laurensia.Irs@ bsi.ac.id
}

Cara Sitasi: Irwanto, Hariatiningsih Laurensia R. Identitas Diri pada Media Sosial (Konstruksi Sosial dan Potensi Rumor Pengguna Instagram. Jurnal Komunikasi 10(2), 184-190.

\begin{abstract}
It is undeniable that Instagram social media has entered in all aspects of communication. At first Instagram just sharing moments of photos and videos and then used for trading and spreading information. Instagram let anyone has the opportunity to attract other user attention by doing social construction from its of the contents through his Instagram account. This research attempts to describe the social construction that occurs and its potential in the dissemination of rumors on social media Instagram. With a qualitative descriptive approach revealed that Instagram users in this case the students are aware of and do message construction in order to get the attention of other users. They also understand that Instagram social media has the potential to spread rumors to the public.
\end{abstract}

Keywords: social media,instagram, social construction, rumors

\section{PENDAHULUAN}

Pada awal kemunculannya aplikasi Instagram (IG) diperuntukkan hanya bagi pengguna iphone saja. Ketika itu pada konsep rancangannya si pengguna (user) hanya sekadar bisa mengunggah foto lalu dapat memperoleh komentar dan tombol like dari pengguna lainnya. Pengguna juga bisa melihat-lihat foto pengguna lainnya di Instagram. Melalui perkembangan teknologi, kini fitur Instagram bisa digunakan pada semua jenis smarthphone atau telepon pintar termasuk yang berbasis android. Fitur yang ditawarkan makin beragam, yang pada awalnya hanya hanya sekedar berbagi foto, belakangan pengguna Instagram bisa mengunggah video bahkan juga bisa siaran live langsung. Instagram saat ini telah dilengkapi dengan kemampuan untuk mengedit gambar lalu memodifikasinya dengan efek khusus yang telah disediakan. Hal ini memungkinkan foto atau video yang diunggah pada Instagram bisa jadi lebih menarik dari realitasnya. Selain itu dengan memanfaatkan Global Positioning System (GPS), pengguna juga bisa berbagi lokasi guna memberi tahu kepada pengguna Instagram lainnya keterangan tentang lokasi foto itu diambil. Foto ataupun video yang diunggah ke Instagram juga bisa terkoneksi dengan jaringan media sosial laianny serta berbagi dengan sesama pengguna.
Kini Instagram menjadi golongan aplikasi media sosial yang mampu menarik perhatian pengguna dengan latar belakang dan usia yang sangat variatif. Fenomena penggunaan Instagram dikalangan remaja remaja tidak bisa dipandang remeh, karena Instagram cenderung mengefisiensikan dimensi sosial pada aspek komunikasi. Diantaranya Instagram mampu menjadi alat silaturahim digital, sarana usaha, penyebar informasi yang cepat dan menjangkau khalayak yang luas dan tidak terbatas, ajang mencari kawan bahkan jodoh, serta wahana memviralkan sesuatu atau seseorang. Selama ada asupan listrik dan kuota pada telepon pintar atau smartphone masih tersedi, maka ketika itu konten foto, video ataupun tulisan bisa diunggah. Konsekuensinya saat itu juga publik relatif dapat mengaksesnya. Proses ini berjalan sangan cepat, bahkan bisa lebih cepat dari industri informasi yang dikelola oleh media massa profesional. Sebab Instagram tidak melewati proses gatekeeper, sementara media massa melaluinya. Hal ini sangat rentan dengan praktek rumor. Konstruksi yang berlebihan pada media sosial Instagram berpotensi menjadi sarana praktek rumor yang berujung pada hoax. 


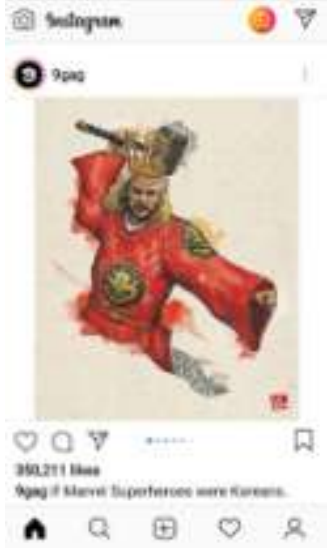

Sumber : akun Instagram 9gag

Gambar 1 : Interface Instagram

Proses komunikasi yang mudah pada Instagram membuka peluang penggunanya dalam hal ini remaja yang sering abai dalam bersikap, bertindak ketika melakukan tindakan komunikasi pada aplikasi Instagram. Terlebih perangkat pada Instagram memungkinkan pengguna bisa menjadi siapapun yang berbeda sekali dengan realitasnya, Baik itu nama, foto profil, tampilan tubuh termasuk manipulasi identitas kelamin, profil sosial bahkan status perkawinan.

Mengarah pada penelitian ini, yakni usia remaja yang masih berada pada taraf proses perkembangan identitas. Paparan interaksi pada remaja yang menggunakan Instagram akan membawa presentasi diri mereka dalam mengidentifikasi dirinya sendiri saat gunakan aplikasi tersebut. Terkait akan hal ini, menjadi penting untuk memahami makna media sosial Instagram Instagram bagi remaja, sikap serta tindakannya dalam berkomuniksi menggunakan media sosial tersebut. Sebab secara personal pengguna Instagram memiliki peluang dan wewenang yang penuh untuk produksi pesan termasuk perihal identitasnya. Ini sangat bertolak belakang pada kehidupan sosialnya secara nyata. Di Instagram yang berada pada dunia maya lebih longgar aturan sosialnya dan terdapat banyak celah bagi penggunanya untuk melakukan konstruksi pesan termasuk identitas. Sementara dalam kehidupan sehari-hari seseorang terikat oleh banyak nilai dan aturan yang berlaku dilingkungan sosial. Fokus penelitian ini berupaya mengungkapkan bagaimana para remaja mengkonstruksi dirinya serta potensi terjadinya rumor pada media sosial Instagram.

\section{Media Sosial Instagram Berada Di Dunia Maya}

Aplikasi media soaial Instagram muncul sebagai buah karya kemajuan bidang teknologi dan komunikasi. Saat ini dunia terhubung secara digital, individu terhubung dengan internet melalui media sosial untuk berinteraksi dengan sesamanya mulai dari sekadar percakapan sederhana, berita dan berbagi berkas kerja. Melalui media sosial seperti halnya Instagram masyarakat pun menemukan alternatif baru untuk menyampaikan opini, gagasan serta ide (Kaplan \& Haenlein, 2010). Instagram sangat populer pada remaja di Indonesia. Media sosial ini pada dasarnya merupakan aplikasi yang memang khusus para penikmat dan praktisi fotografi. Meskipun demikian tidak dapat dipungkiri bila konsep komunikasinya tidak jauh berbeda dengan Facebook. Terlebih Facebook telah mengambil alih saham Instagram pada 9 April 2012. Instagram, mampu menyajikan foto ponsel dan video serta mampu membaginya dengan cepat. Instagram muncul sebagai medium baru dan menjadi sorotan dalam beberapa tahun terakhir. Pengguna bisa secara instan menangkap dan berbagi momen kehidupan mereka dengan teman-teman melalui serangkaian gambar dan video yang bisa dimanipulasi (Hu, Manikonda, \& Kambhampati, 2014a). Saat ini Instagram mampu merebut khalayak karena aplikasi ini tidak hanya fokus pada foto saja namun juga platform video bahkan animasi. Belakangan fitur live juga terdapat pada Instagram sehingga membuat aplikasi media sosial ini mampu menerobos keterbatasan ruang dan waktu.

Berkomunikasi dengan Instagram menjadi menarik karena terdapat berbagai fitur pilihan, diantaranya fitur edit yang mampu menambah estetika pada foto atau video yang diunggah. Selain itu Instagram mampu menghadirkan dimensi komunikasi yang variatif. Pengguna Instagram dapat melakukan komunikasi personal, komunikasi kelompok, bahkan mungkin komuniksi massa. Tergantung fitur yang dipakai pengguna pada Instagram tersebut.

Penggunaan Instagram kini tidak hanya dibatasi hanya sekadar silaturahim digital ataupun kesenangan virtual belaka, namun Instagram bisa dijadikan sarana bisnis (Kaplan, 2012). Hadirnya Instagram juga membangkitkan profesi yang dikenal dengan istilah selebriti Instagram atau selebgram yang memiliki pengikut (follower) bisa mencapai jutaan. Para selebgram adalah pesohor yang datang dari berbagai latar belakang, bisa selebriti yang sudah terkenal terlebih dahulu ataupun pendatang baru. Mereka berasal pehobi kuliner, pecinta fotografi, penikmat kopi, yang suka belanja ataupun aktifitas sosial lainnya.

Penekanan yang perlu dipahami bahwa kenyataannya komunikasi yang terjalin pada Instagram berada dalam dunia maya. Dalam realita ini, setiap perangkat termasuk aplikasi Instagram yang terhubung dengan internet adalah sebuah jendela, apa yang terlihat atau terdengar bukanlah fisik dan bukan representasi objek-objek fisik, namun lebih merupakan gaya, karakter dan aksi pembuatan data, pembuatan informasi. Hal ini bisa dipahami bahwa dunia maya adalah realita yang terhubung secara global yang didukung oleh 
komputer, berakses peralatan teknologi informasi komunikasi, multidimensi, artifisial atau virtual. Dalam pemakaian umum saat ini, dunia maya adalah istilah komprehensif diantaranya untuk world wide web, milis elektronik, kelompok-kelompok dan forum diskusi, ruang berbincang (chatting), permainan interaktif multi player termasuk juga media sosial Instagram.

Dengan menggunakan teknologi internet memungkinkan hampir semua orang di belahan dunia manapun untuk saling berkomunikasi dengan cepat dan mudah. Pada saatnya kebanyakan dari kita (manusia) akan mendapati diri kita berinteraksi dalam dunia maya (Castronova, 2008). Internet menawarkan potensi komunikasi yang lebih terdesentralisasi dan lebih demokratis dibandingkan yang ditawarkan oleh media massa (Severin \& Tankard, Jr, 2014). Keunggulan gunakan jaringan internet sebagai infrastruktur komunikasi karena unsur interaksinya (Croteau, Hoynes, \& Milan, 2012a). Ini berarti kemampuan pengguna untuk berkomunikasi secara langsung dengan komputer dan memiliki dampak pada pesan apapun yang sedang dibuat. Dari pandangan ilmu sosial interaktifitas berarti adanya keterlibatan manusia pada komunikasi dengan gunakan jaringan internet dan adanya tingkatan pada proses komunikasi ketika partisipan memiliki kontrol terhadap peran serta dapat bertukar peran dalam dialog mutual mereka.

Pengguna media sosial termasuk Instagram ini adalah individu yang berada pada jaringan dan saling terikat secara personal yang terhubung dengan computer mediated communication (CMC), memiliki identitas on line (ID), berinteraksi, dan ikut serta bersama dengan (pengguna) yang lainnya dalam komunitas on line (Lipschultz, 2017)

\section{Bahasa dan Teks Pada Instagram Serta Konstruksi Realitas}

Elemen visual gambar baik yang diam yakni berupa foto) ataupun yang bergerak yaitu video serta tulisan yang terdapat pada Instagram bisa dipahami sebagai teks. Sementara secara luas bahasa dipahami sebagai struktur yang dikendalikan oleh aturan main tertentu, semacam mesin untuk memproduksi makna. Teks dalam konteks ini serta bahasa yang menyertainya merupakan alat simbolis untuk mensignifikasi dimana logika ditambahkan secara mendasar kepada dunia sosial yang diobyektifasi. Baik teks dan bahasa itu sendiri mengalami proses konstruktsi pada medan sosial, termasuk ketika digunakan dalam media sosial Instagram. Bahasa memiliki aturan main bila ingin menghasilkan ekspresi yang bermakna. Dengan demikian teks yang berada pada aplikasi Instagram mengandung bahasa yang memiliki struktur agar memiliki makna. Pada proses penggunaan bahasa yang dipakai merupakan hasil konstruksi yang telah mengalami proses dialektika sosial. Fenomena ini bisa dijelaskan dengan konsep dialektika antara diri yang diprakarsai oleh pemikiran Berger dan Luckmann, dalam hal ini pengguna Instagram dengan lingkungan dunia sosial nya. Dialektika ini berlangsung melalui tiga fase. Pertama, penyesuaian diri dengan dunia sosiokultural sebagai produk manusia (eksternalisasi). Kedua, interaksi sosial yang terjadi dalam dunia intersubyektif yang dilembagakan (obyektifitas), Ketiga, proses ketika individu mengidentifikasi dirinya dengan lembagalembaga sosial atau tempat individu menjadi anggotanya atau internalisasi (Berger \& Luckmann, 2011). Tiga momen dialektika itu melalui proses konstruksi sosial yang dilihat dari segi asal mulanya merupakan hasil ciptaan manusia, yaitu buatan interaksi intersubjektif. Pertama, tahapan eksternalisasi berlangsung ketika produk sosial, dalam hal ini bahasa-teks tercipta di masyarakat. Lalu kemudian individu menyesuaikan diri ke dalam dunia sosiokulturalnya sebagai bagian dari produk manusia. Kedua, tahapan obyektifasi produk sosial terjadi dalam dunia intersubjektif masyarakat. Ketiga, tahapan internalisasi yaitu pemahaman atau penafsiran yang langsung dari suatu peristiwa obyektif sebagai pengungkapan suatu makna (Bungin, 2015). Hal ini artinya sebagai manifestasi dari proses-proses subyektif orang lain yang demikian menjadi bermakna secara subyektif bagi individu itu sendiri. Tidak peduli apakah subyektif orang lain itu bersesuain dengan subyektif individu tertentu. Karena bisa jadi individu memahami orang lain secara keliru, sebab sebenarnya subyektivitas orang lain itu tersedia secara obyektif bagi individu dan menjadi bermakna baginya. Kesesuaian sepenuhnya dari kedua makna subyektif dan pengetahuan timbal balik mengenai kesesuaian tersebut mengandalkan pengertian bersama.

\section{Konstruksi Pesan dan Rumor Di Media Sosial} Selama ini konstruksi pesan dengan memanfaatkan alat atau tools pada aplikasi media sosial dianggap hal wajar, seperti halnya manipulasi gambar melalui tools yang terdapat pada fasilitas di media sosial termasuk di Instagram. Pengembang aplikasi menyajikan tools manipulatif foto dengan tujuan untuk memperindah foto yang kurang bagus. Namun saat ini ada pengguna malah menggunakan tools tersebut jauh melampaui kebutuhan. Bahkan ada yang digunakan untuk menyebar kabar rumor bahkan bohong atau yang biasa dikenal hoax. Rumor mudah menyebar pada media sosial termasuk Instagram. Karena keberadaan media sosial yang juga menjadi karakter khasnya yakni berada bukan pada alam nyata dan sangat berpotensi menjadi wahana penyebar rumor yang ampuh. Penggunanya bisa bermetamorfosis semakin merangsang orang untuk menyebar rumor melalui media sosial tidak terkecuali Instagram ini.

Rumor bisa didefinisikan sebagai informasi yang tidak terverifikasi melalui sirkulasi dari 
individu ke individu lain yang terjadi pada jaringan sosial. Biasanya menyebar sangat cepat karena meningkatkan popularitas. Rumor meluas dan hanya butuh hitungan detik untuk membagi (isi) nya tanpa diketahui integritas pesan tersebut $(\mathrm{R} \&$ Mohan, 2017). Rumor bisa berpotensi menjadi hoax serta menimbulkan keresahan sosial dan ironinya Kapolda Metro Jaya menyatakan bahwa hoax dimedia sosial menjadi bisnis (Amelia R, Koesmawardhani, \& Mappapa, 2016). Karena rumor, desas-desus atau hoax di media sosial yang kemudian terbukti salah dapat menimbulkan konsekuensi yang berbahaya baik bagi individu maupun untuk masyarakat (Zubiaga, Liakata, Procter, Hoi, \& Tolmie, 2016). Rumor ini berada dalam jaringan media sosial dan relatif sangat cepat penyebarannya kepada pengguna lain meski dilokasi manapun. Media sosial sering menguatkan dan menyebarluaskan rumor melalui penggunanya yang tersebar luas dimana-mana (Sloan, Quan, \& Haase, 2017).

\section{METODE PENELITIAN}

Penelitian ini menggunakan pendekatan deskriptif kualitatif dengan metode studi kasus yang bersifat deskriptif. Data dikumpulkan melalui wawancara mendalam, observasi dan studi literatur. Penetapan subjek penelitian dilakukan melalui purposif berdasarkan karakteristik sebagai pengguna aktif Instagram, baik pria dan wanita remaja yang usia kisaran antara 14-24 (Bugiardo, 2015). Dalam penelitian ini, yang menjadi objek penelitian adalah konstruksi identitas diri pada media sosial Instagram. Data yang diperoleh dikumpulkan dan diolah terkait dengan subjek dan objek penelitian yang telah ditetapkan melalui oservasi dan wawancara mendalam dengan beberapa informan. Lalu data tersebut dikategorisasi sesuai dengan permasalahan penelitian yang diajukan. Setelah itu peneliti akan mengeksplorasi data lalu menganalisa dan membahasnya dengan mengelaborasinya dengan kajian literatur lalu dipaparkan dalam sebuah penjelasan.

\section{HASIL DAN PEMBAHASAN}

Media sosial menjadi wahana favorit para remaja untuk mengakses berbagai macam informasi yang sesuai dengan kebutuhannya. Media sosial juga mejadi tempat para remaja berinteraksi dengan sesamanya. Meski Instagram yang menjadi media sosial favorit para informan saat ini, namun mereka juga memiliki akun media sosial yang lain seperti halnya twitter, Path, Facebook Line serta linked. Ini sesuai dengan yang dikatakan oleh informan II, yakni :

$$
\begin{aligned}
& \text { Meski yang sering dipake } \\
& \text { Instagram tapi akun medsos } \\
& \text { yang lain twitter,Path, } \\
& \text { Facebook Line serta linked } \\
& \text { masih tetap ada. Akun medsos }
\end{aligned}
$$

\section{lama ga di delet, sesekali dicek \\ kok. Kan anak zaman now makenya Instagram.}

Media sosial selain Instagram tetap menjadi pilihan alternatif para remaja, namun menurut data temuan disini prioritas yang digunakan informan adalah Instagram. Informan meyakini Instagram mampu memberikan layanan komunikasi yang sesuai dengan kebutuhan mereka. Mulai dari mencari berita, informasi tentang artis, selebgram, informasi tentang suatu produk atau layanan jasa, informasi mengenai seseorang yang disukai atau informasi tentang kawannya sendiri (stalking). Selain itu, mereka memilih Instagram karena media sosial ini juga memberikan layanan untuk mempublikasikan ekspresi dan karya mereka dalam bentuk foto dan audio visual. Dari kutipan pernyataan informan yang menyatakan bahwa anak zaman now makenya Instagram. Pernyataan ini menjadi penguat bahwa Instagram menjadi media sosial favorit di kalangan mereka. Wajar bila Instagram digunakan oleh anak remaja. Media sosial ini memberikan variasi mode untuk melakukan pemotretan foto atau pengambilan gambar video, diantaranya : live, normal, boomerang, superzoom, rewind, dan hands free. Kelebihan instagram dengan media sosial lain dan membuat media sosial ini begitu banyak dipakai warganet yakni kemampuan memberikan pengguna cara instan yang dilengkapi filter manipulasi untuk keperluan memotret dan memvideokan berbagi momen kehidupan mereka (Hu, Manikonda, \& Kambhampati, 2014b).

Menurut data yang diperoleh, penggunaan media sosial Instagram pada kalangan usia remaja termasuk dalam frekuensi tinggi, mereka dalam setiap aktivitas kesehariannya tidak lepas dari media sosial tersebut. Hal ini sesuai dengan apa yang dikemukakan oleh hampir semua informan yang mengaku membuka aplikasi Instagram dua sampai tiga kali dengan minimal durasi satu sampai dengan 1,5 jam. Durasi ini digunakan untuk mencari informasi dan mengunggah materi dan melakukan pengecekan mengenai unggahan atau postingan sebelumnya, untuk melihat siapa yang memberikan likes dan comment. Inti dari aktifitas ini semua ialah komunikasi. Mereka paham betul bahwa Instagram adalah salah satu sarana untuk berkomunikasi, baik mengirim ataupun menerima pesan, termasuk di dalamnya berinteraksi dengan sesama pengguna Instagram.

Dari data temuan diperoleh informasi bahwa subjek penelitian menyadari dan sepakat bahwa media sosial Instagram adalah sarana berkomunikasi dengan konsep satu menuju semua. Sebagaimana laiknya berkomunikasi, Instagram dianggap oleh informan sebagai medium perantara untuk berkomunikasi, termasuk memperoleh serta mengirim informasi. Hanya saja dengan Instagram sebagian besar subjek sepakat bahwa media ini memiliki kelebihan, yakni bisa berinteraksi dengan 
orang yang terlibat dalam sebuah tema komunikasi (postingan). Hal ini merupakan bukti pengukuhan bahwa komunikasi dengan menggunakan media sosial Instagram dapat ditelaah melalui perspektif komunikasi. Penelitian ini akan membahas makna penggunaan media sosial Intagram, identifikasi diri, sikap serta tindakan dalam berkomunikasi pada media sosial Instagram bagi penggunanya, dalam hal ini yang berusia remaja.

\section{Media Sosial Instagram Dan Konstruksi Sosial Mencari Perhatian}

Melalui keungulan teknologi yang berdampak pada tampilan dan menu Instagram serta kemampuan mengakomodir kebutuhan komunikasi para penggunanya, maka Instagram menjadi pilihan warganet khususnya para remaja. Motif komunikasi informan saat menggunakan Instagram pada dasarnya ingin mendapatkan respon positif. Pertama bisa berbentuk like dan comment yang banyak atau konten yang diunggah menjadi viral lalu jadi perbincangan warganet. Ini sesuai dengan pernyataan sebagian besar para informan, diantaranya informan I :

Saya mengharapkan like dan komentar dari apa yang saya posting

Ada rasa kebanggan bila berhasil mengumpulkan like dan comment yang banyak dan menjadi viral. Secara psikologis penggun atau user jenis ini membutuhkan perhatian orang lain, lalu memanfaatkan media media sosial sebagai upaya mencapai keinginannya itu. Ini sangat sinkron bila dikaitkan dengan hasil penelitian, bahwa pengguna Instagram sadar atau tidak telah mengaplikasikan konsep impression management atau manajemen kesan. Remaja pengguna Instagram menerapkannya saat membuat konten yang berupa foto dan atau tulisan yang menyertainya.

Respon kedua yakni respon pembeli, hal ini diperuntukkan bagi yang menjadikan Instagram sebagai sarana komunikasi periklanan maka tidak lain agar jualannya laku. Bagi remaja pengguna Instagram yang menjadikan akunnya sebagai sarana berjualan, maka apapun yang diunggah harus bisa menghasilkan uang. Respon yang ini mengandung motif ekonomi karena jualan laku menjadi dasar bagi tiap materi yang akan diunggah.

Kedua respon ini, baik motif memperoleh like dan comment yang banyak, dan respon yang mengandung motif ekonomi keduanya sama-sama mencari perhatian dari warganet. Mencari perhatian menjadi landasan utama informan ketika akan membuat materi untuk diunggah pada akun Instagramnya. Memperoleh perhatian adalah harapan bagi pengguna Instagram. Pada penelitian ini mendapati fakta bahwa realitas konten bentuk apapun yang akan diunggah pengguna Instagram ialah sebuah aktifitas komunikasi yang mengkonstruksi pesan dengan tujuan akhir memperoleh perhatian. Kesan diperoleh dengan mengemas pesan yang dikonstruksi sebelumnya agar memperoleh perhatian. Pengguna atau user disini eksis sebagai manusia dengan tindakan komunikasi melalui gawainya. Ia melakukan unggahan atau uploading, dan obrolan atau chatting. Melalui hal tersebut ia berbagi untuk kebutuhan akan pengakuan (Hardiman, 2018).

\section{Foto Pada Instagram, Konstruksi dan Impression Manajemen}

Informan menganggap Instagram memiliki kekuatan yang mampu membentuk dan mengubah persepsi orang lain akan jati diri penggunanya. Profil foto serta materi yang akan diunggah telah melalui proses konstruksi oleh pembuatnya. Data yang diperoleh dari penelitian ini mengatakan bahwa identitas pengguna akun Instagram akan diidentifikasi orang lain melalu foto dan nama yang ditampilkan dalam akunnya. Hal inilah yang pertama kali dibentuk ketika saat awal akun Instagram dibuat. Pada proses ini kesempatan bagi para pengguna Instagram untuk menampilkan foto profil yang terbaik agar mendapatkan kesan baik dimata orang lain sehingga bisa memperoleh dan menambah pengikutnya (follower) .

Terdapat beberapa alasan yang diutarakan oleh para informan tentang pentingnya foto pada profil, benang merah dari alasan-alasan tersebut yakni kesan pertama haruslah bagus terutama tampilan pada foto profil. Pada foto ini hal pertama yang dilihat oleh orang lain, seperti yang disampaikan oleh informan II :

Karena yang pertama dilihat orang adalah foto profil dulu, kalo fotonya ga bagus nanti gak jadi di follo.

Kesan orang lain terkait profil menjadi prioritas oleh pengguna Instagram, khusunya pada foto profil. Kembali unsur kesan menjadi alasan informan. Pada foto ini identitas diri dikonstruksi, bahkan sebagian besar informan yang diwawancarai menyatakan bahwa melakukan editing pada foto profil adalah hal yang mutlak dilakukan. Tujuaanya tidak lain memperoleh kesan guna mendapat perhatian dari warganet. Sebagaimana yang disampaikan oleh informan I :

Edit foto perlu supaya tampilannya bagus Ini menegaskan bahwa informan tidak bisa menerima kondisi sebagaimana adanya yang terdapat dalam foto tersebut. Ia berupaya menampilkan fotonya yang bagus agar memeproleh kesan dan perhatian warganet. Maraknya proses edit foto ini juga dibuktikan dengan banyaknya aplikasi edit foto yang tersedia pada google play store. Ini bebarti makna foto yang bagus atau tampilan foto yang bagus dalam benak informan adalah sesuai dengan perspektif si pembuat aplikasi edit foto tersebut dan bukan yang alami. Para informan tidak menyadari bahwa media sosial Instagram telah berhasil mendominasi makna foto 'bagus' dirinya 
menjadi dominan dikuasai oleh perspektif si pembuat aplikasi edit foto.

Pengguna Instagram ingin mendapatkan kesan pertama yang baik, sehingga mereka melakukan konstruksi pada foto profil dengan menerapkan konsep manajemen impresi terhadap fotonya. Dipahami manajemen kesan sebagai keinginan individu dalam mempresentasikan dirinya sebagai seseorang yang bisa diterima oleh orang lain (Goffman, 1999). Informan telah membentuk citra diri, menata dan menjaganya melalui tampilan foto profil dengan tujuan mendapatkan kredit positif dari orang lain.

Foto profil menjadi etalase pada pengguna Instagram sehingga mereka berlomba menghias etalase tersebut dengan foto yang telah disiapkan dengan teknik pengambilan yang foto ataupun melakukan proses editing pada foto tersebut. Proses pengambilan foto dan memilih foto dari sekian foto yang akan diunggah menjadi foto profile juga termasuk kategori melakukan konstruksi untuk memperoleh kesan positif bagi orang yang melihatnya. Tuntutan diri untuk menampilkan foto yang bagus tidak hanya pada profil saja, tapi informan juga menerapkannya pada semua foto yang akan diunggah pada akun Instagram miliknya.

\section{Konstruksi Berlebihan Ciptakan Hoax}

Sifat dan karakter media sosial Instagram yang memungkinkan penggunannya untuk melakukan konstruksi sangat rentan dengan penyebaran rumor bahkan hoax. Peluang penyebaran rumor ini bisa terjadi pada biodata profil pengguna dan postingan foto, video ataupun konten yang terdapat pada Instagram. Identitas asli dan karakter asli pengguna secara pasti tidak bisa ditemui melalui profilnya. Karena profil pada Instagram bukanlah katu identitas berbentuk fisik yang resmi seperti laiknya kartu tanda penduduk di dunia nyata (KTP). Instagram berada pada dunia maya yang memungkinkan pengguna bisa menjadi orang lain dengan mengkonstruk serta mengemas dirinya sesuai dengan yang dikehendaki. Tidak ada jaminan hukum terhadap kebenaran dari profil yang terdapat pada media sosial Instagram. Ini seperti yang disampaikan informan VI :

\section{Khawatir takut ada yang mengatas namakan kita dan menggunakan Instagram dengan niat buruk.}

Kalimat ini memberikan petunjuk siapa pun bisa menjadi orang lain atau siapa saja ketika berada pada Instagram.

Sebagian besar informan menyadari bila beberapa profil pengguna media sosial Instagram yang merupakan rekaan dan sebatas imajinasi pengguna lain. Seperti yang disampaikan oleh informan II,III, IV dan VI yang intinya mengetahui bahwa tidak semua profil yang ditampilkan pengguna lain pada Instagram nya sesuai dengan karakter penggunanya. Lalu informan yang sama juga menyadari akan resiko kabar rumor bahkan hoax yang terdapat pada Instagram, akan tetapi terkadang mempercayainya begitu saja.

Menarik dalam hal ini terkait pernyataan informan, bahwa pada penelitian ini informan yang menggunakan Instagram pada dasarnya paham tentang peluang melakukan konstruksi saat penggunaan aplikasi ini, namun tidak selamanya menyadari bahwa konstruksi tersebut bisa saja merugikan mereka. Padahal melakukan konstruksi yang berlebihan untuk mencari perhatian bisa dikategorikan sebagai hoax dan terkena sanksi hukum. Namun masih saja ada yang membuat rumor dan hoax meskipun sudah ada undang-undang ITE dengan ancaman sanksi hukum terhadap penyebar berita palsu melalui media sosial. Ironisnya ada juga yang mudah begitu saja percaya berita rumor atau hoax yang disebar melalui Instagram padahal seharusnya mereka bisa mengkonfirmasi berita tersebut melalui gawai yang mereka miliki dengan memanfaatkan mesin pencarian yang terdapat di dalamnya, namun kenyataannya tidak semua orang melakukan konfirmasi. Karena rumor biasanya menyangkut hal yang sedang popular atau menarik perhatian masyarakat. Warganet yang termakan rumor biasanya menaruh perhatian tinggi akan materi yang disebarkan tersebut. Konstruksi yang dilakukan berlebihan mampu mempengaruhi orang dan rumor yang sesuai dengan opini dan sikap akan lebih mudah dipercaya walaupun bukan realitas yang sesunguhnya. Dengan kata lain orang lebih cenderung percaya hoax jika informasinya sesuai dengan opini atau sikap yang dimilikinya (Respati \& Asril, 2017)

\section{KESIMPULAN}

Media sosial seperti halnya instagram akan terus berkembang baik dari segi fitur ataupun jumlah penggunanya. Dari titik ini potensi penyalahgunaan media sosial oleh penggunanya akan semakin besar. Bila menyimak berbagai penyalahgunaan media sosial yang terjadi di masyarakat saat ini telah menjadi invasi sosial yang butuh penanganan serius. Banyak variabel yang menyebabkan hal ini terjadi. Dibutuhkan penelitian lebih lanjut di ranah media sosial agar ditemukan solusinya. Selain itu sudah saatnya literasi penggunaan media sosial terus dioptimalkan melalui berbagai aspek, termasuk dalam lembaga pendidikan formal.

\section{DAFTAR PUSTAKA}

Amelia R, M., Koesmawardhani, N. W., \& Mappapa, P. L. (2016, Desember 30). Kapolda Metro: Hoax di Medsos Jadi Bisnis, Perlu Ditemukan Pengorder. detiknews. Diambil dari https://news.detik.com/wawancara/d-

3384601/kapolda-metro-hoax-di-medsos-jadi-bisnisperlu-ditemukan-pengorder 
Berger, P. L., \& Luckmann, T. (2011). The Social Construction Of Reality. New York: Open Road Integrated Media.

Bugiardo. (2015). Berkomunikasi Ala Net

Generation Jakarta. Jakarta: Elex Media

Kumputindo.

Bungin, M. B. (2015). Sosiologi Komunikasi, Teori, Paradigma dan Diskursus Teknologi Komunikasi di Masyarakat. Jakarta: Kencana Prenadamedia Group. Castronova, E. (2008). Exodus To The Virtual World. New York: St. Martin's Griffin.

Croteau, D., Hoynes, W., \& Milan, S. (2012a). Media Society: Industries, Images and Audiences. California: Sage Publication.

Croteau, D., Hoynes, W., \& Milan, S. (2012b). Media Society: Industries, Images and Audiences. California: Sage Publication.

Goffman, E. (1999). The Presentation of Self in

Everyday Life. New York: Anchor

Books/Doubleday.

Hardiman, F. B. (2018). Homo Digitalis-Kondisi

Manusia di Era Komunikasi Digital. Etika

Komunikasi Digital Membela Moralitas Dalam

Prahara Politik Pasca Kebenaran. Dipresentasikan pada Seminar Dies Natalis 49 Sekolah Tinggi

FIlsafat Driyakarya.

Hu, Y., Manikonda, L., \& Kambhampati, S. (2014a). What We Instagram: A First Analysis of Instagram Photo Content and User Types. Departemen of Computer Science. Dipresentasikan pada Proceedings of the Eighth International AAAI Conference on Weblogs and Social Media, Arizona. Diambil dari

https://www.aaai.org/ocs/index.php/ICWSM/ICWS M14/paper/view/8118/8087

Hu, Y., Manikonda, L., \& Kambhampati, S. (2014b). What We Instagram: A First Analysis of Instagram Photo Content and User Types. Proceedings Of The Eighth International Conference On Weblogs And Social Media, 595598. Diambil dari https://www.aaai.org/ocs/index.php/ICWSM/ICWS M14/paper/viewFile/8118/8087

Kaplan, A. M. (2012). If You Love Something, Let It Go Mobile: Mobile Marketing And Mobile Social Media 4x4. Elsevier Indiana University Indianapolis, 55(2), 129-139.

Kaplan, A. M., \& Haenlein, M. (2010). Users of the World, Unite! The Challenges and Opportunities of Social Media. Elsevier Indiana University Indianapolis, 53(1), 59-68.

Lipschultz, J. H. (2017). Social Media

Communication: Concepts, Practices, Data, Law

and Ethics (Second Edition). New York: Routledge. R, K., \& Mohan, A. K. (2017). Inspecting Irresponsible Hypes: Rumors in Social Media Networks. International Journal on Computer Science and Engineering (IJCSE), 9, 333-337. Respati, S., \& Asril, S. (2017, Januari 23). Mengapa Banyak Orang Percaya Berita hoax? Kompas.com.
Diambil dari

https://nasional.kompas.com/read/2017/01/23/18181

951/mengapa.banyak.orang.mudah.percaya.berita.ho

ax.

Severin, W. J., \& Tankard, Jr, J. W. (2014).

Communication theories: Origins, Methods and

Uses in The Mass Media (Fifth edition). Harlow, United Kingdom Pearson.

Sloan, L., Quan, A., \& Haase. (2017). Social Media Research Methode. California: Sage Publication. Zubiaga, A., Liakata, M., Procter, R., Hoi, W. S., \& Tolmie, P. (2016). Analysing How People Orient to and Spread Rumours in Social Media by Looking at Conversational Threads. Public Library of Science, 13, 1-29. https://doi.org/10.1371

\section{PROFIL PENULIS}

Irwanto, latar belakang akademik S1 Jurnalistik Institut Ilmu Sosial dan Ilmu Politik (IISIP) Jakarta dan tamat pascasarjana dengan konsentrasi media politik Universitas Mercu Buana Jakarta. Saat ini sebagai dosen tetap Universitas Bina sarana Informatika.

Laurensia Retno H, S.I.Kom, latar belakang akademik S1 Broadcasting di Sekolah Tinggi Ilmu Komunikasi Profesi Indonesia (Stikom Prosia) Jakarta dan sedang melanjutkan studi di Pascasarjana Sahid Jakarta dengan konsentrasi Media Baru dan Jurnalistik. Saat ini status sebagai dosen tetap Universitas Bina Sarana Informatika. 